University of Miami Law School University of Miami School of Law Institutional Repository

1975

The Third United Nations Conference on the Law of the Sea: the 1975 Geneva Session

John R. Stevenson

Bernard Oxman

Follow this and additional works at: https://repository.law.miami.edu/fac_articles Part of the Law of the Sea Commons 


\title{
THE THIRD UNITED NATIONS CONFERENCE ON THE LAW OF THE SEA:

\author{
THE 1975 GENEVA SESSION *
}

\author{
By John R. Stevenson * and \\ Bernard H. Oxman **
}

The second substantive session of the Third United Nations Conference on the Law of the Sea was held at Geneva from March 26 to May 10, 1975. It was decided at the outset that this would be a negotiating session. There was no general debate. Few formal meetings were held. Even informal working groups of the whole tended to rely on smaller groups the work of which was necessarily removed from public view. Progress, in many respects substantial progress, was made toward producing generally acceptable texts in this way. However, the Conference did not complete the negotiation of a new Law of the Sea Convention or approved texts.

The Conference has recommended to the United Nations General Assembly that another session be held in early 1976, and that this session be authorized to convene a further session in 1976 if necessary. ${ }^{I}$ It also requested that arrangements be made to afford interpretation and other logistical support to informal intersessional work, plans for which were already well underway at the end of the Geneva session.

The principal procedural result of the Geneva session was the preparation of informal single texts covering all substantive subjects before the Conference. ${ }^{2}$ Pursuant to the recommendation of the Conference President, endorsed by the Conference by consensus, the single texts were prepared by the Chairmen of the three Main Committees. They are intended to serve as a basis for negotiation of a comprehensive treaty and do not represent agreed articles or consensus texts; they represent the judgment of

- This article is a sequel to Stevenson \& Oxman, The Preparations for the Law of the Sea Conference, 68 AIIL 1 (1974), and The Third United Nations Conference on the Law of the Sea: the 1974 Caracas Session, 69 AJIL 1 (1975). The views expressed herein are those of the authors and do not necessarily represent the views of the Department of State or the U.S. Government.

- Of the Board of Editors. Member of the New York Bar. Until May 10, 1975, Ambassador, Special Representative of the President for the Law of the Sea Conference and Chief of U.S. Delegation.

$\cdots$ Assistant Legal Adviser for Oceans, Environment and Scientific Affairs, U.S. Department of State; U.S. Representative in Committee II, Geneva Session of Law of the Sea Conference.

${ }^{1}$ Letter of May 19, 1975 from the President of the Conference to the President of the General Assembly, UN Doc. A/10121, June 18, 1975.

2 Informal Single Negotiating Text, A/CONF.62/WP.8, May 7, 1975 (hereinafter SNT); reprinted at 14 ILM 682 (1975). Its three PARTs contain the submissions of the Chairmen of the three Main Committees; these in turn are also divided into parts. The three main PARTs are referred to herein in upper case. 
Committee Chairmen, based on their assessment of the negotiations thus far, as to the appropriate starting point for further negotiations during the intersessional period and at the next session. The Co-Chairmen of the Informal Working Group on Settlement of Disputes also submitted a text to the President of the Conference. The President prepared and circulated a single negotiating text on dispute settlement some months later. ${ }^{3}$

Since the single negotiating texts of the Main Committee Chairman were distributed on the last day of the session, they were not the subject of debate or negotiation as such. However, in some important respects they do reflect a basis for agreement that emerged in informal negotiations. This is particularly true of the Committee II text, which took account of the texts on the economic zone that emerged from the daily meetings of the Informal Group of Juridical Experts from some 40 nations from all regions (chaired by Minister Jens Evensen of Norway and known as the "Evensen Group") and complementary work of the Group of 77 (now composed of over 100 developing countries); texts worked out by informal groups set up by the Chairman of Committee II on a wealth of detailed provisions regarding the territorial sea and the high seas; a text on straits prepared by an inforrnal group of moderate nations from all regions chaired by Fiji and the United Kingdom; and other negotiations.

A detailed analysis of the single negotiating texts is beyond the scope of this article. However, an examination of these texts can provide a useful basis for explaining the work done at Geneva and for discussing some of the problems the Conference faces. Moreover, it would not be surprising to find many of the provisions of these texts in the eventual treaty.

The basic structure of the law of the sea which the texts reveal reflects a possible basis for widespread agreement that has been emerging over several years. The ten main elements of that possible agreement are:

(1) a maximum 12-mile limit for the territorial sea, over which the coastal state will have sovereignty, subject to a right of innocent passage, with some elaboration of the rules of innocent passage;

(2) unimpeded passage of straits used for international navigation for all vessels and aircraft;

(3) a 200-mile economic zone in which the coastal state exercises sovereign rights over the exploration, exploitation, conservation, and management of living and nonliving resources and in which all states continue to enjoy freedoms, in particular of navigation and overflight and other uses related to navigation and communication; coastal state sovereign rights over the exploration and exploitation of the resources of the seabed and subsoil of the continental margin where it extends beyond 200 miles, coupled with a duty to contribute some international payments in respect of mineral production in the area of the margin beyond 200 miles;

(4) comprehensive coastal state control of all drilling and of all economic installations in the economic zone;

${ }^{3}$ SD.Gp/2nd Session/No.1/Rev.5, May 1, 1975; reprinted at 14 ILM 762 (1975). Informal Single Negotiating Test (Settlement of Disputes). A/CONF.62/WP.9, July 21, 1975. 
(5) some adjustment and modernization of the regime of the high seas, for example the recognition of the special interest and responsibility of the state of origin for anadromous species of fish and new rules with respect to control of unauthorized broadcasting and cooperation in the suppression of illicit traffic in narcotics;

(6) an elaboration of a concept of island nations as archipelagic states which includes a precise definition of a new category of archipelagic waters and a regime of unimpeded passage through archipelagic sealanes and air routes that traverse the archipelago;

(7) international standards to prevent and control marine pollution, and limited coastal state enforcement rights with respect to vessel-source pollution;

(8) specified coastal state and flag state rights and duties with respect to scientific research in the economic zone and on the continental shelf, and general provisions regarding international cooperation in marine scientific research and transfer of marine technology;

(9) an international regime and machinery to deal with the exploration and exploitation of seabed resources beyond the limits of national jurisdiction (that is, beyond the economic zone or continental margin);

(10) a system for peaceful third-party settlement of disputes regarding the interpretation or application of the Convention which have not been resolved by negotiation or other agreed procedures.

The work of the First Committee embraces point 9. The work of the Second Committee embraces points I through 6 . The work of the Third Committee embraces points 7 and 8. Point 10 is of course related to the work of all three Main Committees. An informal open ended group on peaceful settlement of disputes met several times each week.

For the past few years, many delegations have made it clear that their willingness to accept one or more of these elements is dependent upon the acceptance of other elements. There are almost as many major linkages in this regard as there are major issues. Accordingly, while it is convenient to examine the negotiation in terms of the work of different committees and groups, one must bear in mind the substantive and political relationships between different issues. There was no evidence in Geneva of general movement away from the concept of a single comprehensive treaty-the so-called "package deal." There was, however, encouraging evidence of a general willingness to avoid unnecessarily complicating the negotiations with issues not central to the global accommodation being sought.

\section{The Frast Commttree}

Basically, the resources in question in the international area (the "Area") at this time are the manganese nodules lying at or near the surface of the deep seabed, mostly at depths of 12,000 feet or more.

The fundamental problem addressed in Committee I was that of reconciling the views of those favoring a system of direct exploitation by the new 
international Authority to be established with the views of those interested in assuring guaranteed access to, and production of deep seabed minerals by states and their nationals under reasonable conditions with security of tenure. The progress made in exploring ways to bridge this gap revolved around attempts to elaborate "basic conditions" of a system of exploitation. It was, of course, also recognized that there are other critical elements of any accommodation, in particular the decisionmaking process of the Authority.

The Geneva session commenced in a conciliatory mood. The Group of 77 took the view that it had made an important concession at Caracas in agreeing to include basic conditions of exploitation in the treaty. Moreover, its leadership indicated that there might be some new flexibility on decisionmaking and other issues related to the structure and procedures of the international Authority (usually referred to as international "machinery" issues). Others also came to Geneva prepared to be more flexible on issues of direct concern to the developing countries. The United States Delegation expressed its willingness to consider basic conditions in the treaty as opposed to detailed regulatory provisions (on the condition that detailed regulations for the provisional period would be adopted by the Conference) and to consider a system of joint ventures, with the possibility of profit sharing, as the single method of exploitation.

The Committee devoted the first half of the session to consideration in its Working Group of basic conditions of exploitation. The Group agreed to discuss basic conditions applicable to joint ventures, recognizing that the Group of 77 reserved its position on whether the Authority would directly exploit. A consensus emerged that the legal problems involved in establishing equity joint ventures might be very difficult. Accordingly, the Chairman of the Working Group undertook to prepare a draft set of basic conditions that would be applicable to a contractual rather than an equity joint venture system.

The effort to find a set of basic conditions that would at the same time accommodate the desires for direct and effective control and for guaranteed access was arduous. New means seemed necessary for resolving the dilemma. Accordingly, in the Working Group, the United States explored a system for the reservation of areas: under this "banking system," an applicant for a joint venture would submit two mine sites of equal size, one of which the Authority would designate as a reserved area. With respect to the reserved areas, the Authority could negotiate with any state or its nationals for the most favorable financial terms and commitments to transfer technology. With respect to the other area, arrangements between the Authority and the applicant would be made in accordance with specified provisions in the treaty and basic conditions.

At the same time that the Group of 77 was considering the idea of a banking system, the U.S.S.R. introduced a draft of basic conditions that would be applicable to a parallel system in which the Authority would directly exploit a portion of the seabed by itself or under contract with 
private entities, while another portion of the area would be reserved ex. clusively for state access.*

At midsession the Chairman of the Working Group introduced a personal draft of basic conditions that focused primarily on a contractual joint venture system, including reservation of areas for exploitation by states and for direct exploitation by the Authority. This parallel system was intensively considered by the Group of 77 , which eventually rejected the concept of designating areas solely for state exploitation and also rejected the parallel system as elaborated in the draft.

With little time left, the Chairman deleted these aspects of his draft of basic conditions from the text which he submitted to the Chairman of the First Committee, and which appears as Annex I of the single negotiating text. The deadline for the text came at precisely the wrong time to permit any further reconciliation of positions.

A similar problem existed with respect to the rest of the First Committee single negotiating text. At the request of the Committee Chairman, the Working Group Chairman prepared a first draft which largely reflected developing country positions. He then began intensive private consultations which showed every promise of producing a possible basis for agreement. By the time the Working Group Chairman had a sufficient basis to prepare and to submit a revised text, the deadline had been passed. Accordingly, while widely distributed among Conference participants, the revised text of the Working Group Chairman (the "Pinto text"), which reflected his conclusions from intensive consultations, is not presented in the single negotiating text.

The first part of the Committee I single negotiating text, which contains nineteen articles dealing with the legal regime for the deep seabed, embodies treaty articles on which both the UN Seabed Committee and the Caracas session of the Conference concentrated and reflects greater progress toward a consensus than the remaining articles on the Authority and the annexes on the system of exploitation.

The single negotiating text does indicate certain steps taken in the negotiation toward an eventual accommodation on the machinery issues dealt with in the second part of the text. While these largely continue to reflect the views of the Group of 77 on the nature of the accommodation, the means for achieving that accommodation can be discerned in the text. Three points are critical.

First, a comparison of Article 26 and Article 28 indicates that a Council of limited size, rather than a plenary Assembly, will make many of the important decisions regarding supervision of resource activities. Negotiations are likely to focus on the degree to which the Assembly or the Contracting Parties can override or lay down guidelines controlling such decisions.

Secondly, Article 27 provides for the inclusion within the 36-member Council of six members with substantial investment, or possessing advanced

4A/CONF.62/C.1/L.12, March 21, 1975. 
technology being used, in exploration and exploitation of the Area, or which are major importers of landbased minerals also produced from the Area; it also requires that decisions on important questions be taken by a majority of two-thirds plus one. This reflects a willingness to depart in principle from selection solely on the basis of equitable geographic representation. As a practical matter, however, the limitation to six in a Counciil of 36 and the discretion of the Assembly to elect states meeting the criteria without regard to their relative rank are likely to render the article unsatisfactory from the standpoint of those countries with the greatest potential investment and the most advanced technology. Negotiations are likely to focus on the required voting majority (in the Pinto text, threequarters) and on the number and basis of selection of the developed countries on the Council (the Pinto text requires nine, comprising the most industrialized countries with substantial investment in or substantial technology with respect to the Area and its development).

Thirdly, Article 32 establishes a special tribunal with comprehensive jurisdiction over disputes not only between states parties, but between a state or a private contractor and the Authority. Article 58 makes clear that this includes review of actions by the Authority and its organs. Negotiations are likely to focus on (i) the relationship of this review to the distribution of powers in the Authority and to the general dispute settlement articles of the Law of the Sea Convention and (ii) the permissibility of contractual arrangements that seek to circumvent review by the tribunal.

It would appear that negotiations on these and related articles will continue to involve the demand, reflected in Article 26, that the Assembly be the "supreme policy-making organ of the Authority." Article 28 provides that the Council "shall act in a manner consistent with general guidelines and policy directions laid down by the Assembly." Any protection of industrial country interests built into the Council will be essentially nugatory if Council decisions may be reversed or circumscribed by an Assembly operating on a one-nation one-vote principle.

Article 28 does not provide for review of Council rules, regulations, and procedures by Contracting Parties before they enter into force; yet a direct role for Contracting Parties may be one of the best ways to achieve an accommodation of the objective of broad review and concerns about the role of the Assembly.

The views of landbased producers of minerals found in manganese nodules continue to dominate the philosophy of the text; this is manifested in particular by the absence of any express requirement that exploitation that satisfies the necessary treaty conditions should be permitted (aside from the requirement that the Authority enter into joint ventures in respect of the first "ten economically viable mining sites"). ${ }^{5}$ However, consumer interests have in fact made themselves felt increasingly among both developed and developing countries. Thus, while Article 30 would establish an Economic Planning Commission that could make recommendations

5 SNT, PART I, Art. 22. 
to the Council to protect landbased producers, the criterion of protecting only "developing countries whose economies substantially depend on the revenues derived from the export of minerals" also derived from the Area and the admonition to bear in mind "the interests of both consuming and land-based mineral producing countries" reflect a continuing and growing recognition that countries with weak but developing economies may be hurt if supplies are kept artificially low and prices artificially high.

The article of the Committee I text most critical to progress in the negotiations is Article 22, which provides that exploitation shall be conducted directly by the Authority, which "may, if it considers it appropriate," enter into arrangements with states or private parties for this purpose. Unless there is a substantial qualification of this article to provide for assured access and production by states and their nationals, an underlying accommodation will not have been achieved.

There is good reason to believe that the will to find such a breakthrough is present; it is widespread although perhaps not articulated with sufficient vigor in the Group of 77. Perhaps the best example of this positive will is reflected by the restraint shown on the issue of voting a new moratorium on deep seabed exploitation. The UN General Assembly resolution ${ }^{6}$ on this matter was passed over the negative votes of the United States and other industrialized countries. Despite strong efforts by some in the Group of 77 to produce a new moratorium resolution, it was in fact recognized that raising this divisive issue could have adverse consequences for the negotiations. Instead, the President of the Conference, on the last day of the Geneva session, made a statement on the issue in which he said, inter alia:

I should like to make a fervent appeal to all States to refrain from taking any action, and also to use their powers to restrain their nationals from taking any action or adopting any measures, which would place in jeopardy the conclusion of a universally acceptable treaty of a just and equitable nature.

\section{The Second Comimttee}

By far the largest and most diverse number of issues and the disposition of the most vital and valuable resources of the oceans at this time were entrusted to the Second Committee. It entered the Geneva session with a paper developed at Caracas to reflect the "main trends" of the discussion and which set out a clear and limited number of alternatives on virtually every issue. ${ }^{7}$ That paper made orderly negotiation possible. Eight weeks later, the Chairman of Committee II produced a single text that, to a varying yet significant degree, does reflect actual negotiating progress made under the auspices of the Committee officers and in informal but representative groups. Those who cited the sheer number of

${ }^{6}$ GA Res. 2574D (XXIV); GAOR, 24th Sess., Supp. 30, at 11, UN Doc. A/7630 (1969).

A/CONF.62/C.2/NP.1. 
issues involved as the basis for predicting an interminable and unmanagoable negotiation have not yet been proven wrong. But with the Committee II single negotiating text as the point of departure, there is every reason to believe that with restraint, careful intersessional negotiation, and procedures designed to encourage the widest possible agreement, a successful result in this Committee is within reach.

The basic structure of a 12-mile maximum territorial sea, unimpeded passage of straits, and a 200-mile economic zone with sovereign rights over living and nonliving resources and special treatment for anadromous species (salmon) has now been elaborated by specific texts negotiated in various groups which were used as a basis for the single negotiating text, with work continuing on an article on highly migratory species (tuna). Those texts have not been agreed to by the Conference as a whole but do reflect negotiations among informed and articulate proponents of the main trends at the Conference and as such may provide a basis for general agreement.

The atmosphere in the Second Committee and related negotiations was extremely workmanlike. During the review of the Main Trends Paper, ${ }^{8}$ there was little repetition of positions already known. The major exception concerned persistent efforts by a handful of strait states to reopen that paper; the overwhelming view was that it would be a retrograde step to concentrate further on the elaboration of alternatives.

Many ad hoc informal groups met to consider specific issues under the guidance of the Committee officers; while open to all, the groups were generally of manageable size. An impressive number of informal draft articles emerged from these groups. These articles are reflected in the single negotiating text and are likely to command broad support. They deal with virtually all of the traditional aspects of the territorial sea regime, including baselines and innocent passage, and the high seas regime, with some technical changes in and elaborations of the existing regimes. An informal group of moderates elaborated a set of articles on unimpeded passage of straits used for international navigation.

The Evensen Group produced a "sixth revision" text on the economic zone on April 16, 1975, which was circulated to all delegations. This text reflects a broad trend of opinion. However, its circulation was followed by efforts by extreme territorialists in the Group of 77 to make the economic zone more coastally oriented and by efforts by landlocked and geographically disadvantaged states to secure greater rights of access to fisheries of neighboring coastal states. On fisheries, both the Evensen text and the single negotiating text include articles on conservation and full utilization and an article on anadromous fish (salmon) protecting the interests of the state of origin. While no agreement has yet emerged on continental shelf jurisdiction beyond 200 miles, both the latest draft Evensen text (still under consideration) and the single negotiating text reflect the view of many moderates that coastal state jurisdiction extending to a

${ }^{8}$ Ibid. 
precisely defined limit of the continental margin beyond 200 miles coupled with revenue sharing beyond 200 miles is the only way to achieve widespread agreement.

\section{The Territorial Sea and Contiguous Zone}

The single negotiating text reflects the general view expressed by delegations in favor of a maximum limit of 12 nautical miles for the territorial sea and retention of existing regimes regarding baselines and innocent passage with some elaboration and technical changes. While Ecuador formally revived a proposal for a 200 -mile territorial sea, ${ }^{8}$ it received little support; even some supporting statements were ambiguous.

The provisions in the single negotiating text on baselines from which the breadth of the territorial sea is measured contain some interesting new elements ${ }^{10}$ not found in the 1958 Convention on the Territorial Sea and the Contiguous Zone. ${ }^{11}$

Considerable time was devoted to an elaboration of the rule in the 1958 Territorial Sea Convention that passage is innocent so long as it is not prejudicial to the peace, good order, or security of the coastal state. ${ }^{12}$ While doubts were expressed as to whether an exhaustive list of noninnocent activities could be prepared, others noted that the goal of "objectivizing" innocent passage indicated the desirability of attempting such an approach. Article 16 elaborates a dozen activities which would render

${ }^{9} \mathrm{~A} / \mathrm{CONF} .62 / \mathrm{C} .2 / \mathrm{L} .88$, April 18, 1975.

10 Article 5 provides that in the case of islands situated on atolls or of islands having fringing reefs, the baseline shall be the seaward edge of the reef. Article 6 provides that straight baselines may connect appropriate points along the furthest seaward extent of the low-water line notwithstanding subsequent regression of the low-water line where, because of the presence of a delta or other natural conditions, the coastline is highly unstable. Some attempts were made to define historic bays with greater precision; it is indicative of the general workmanlike atmosphere that after a few meetings on the issue it was recognized that the effort could be very time consuming and might adversely affect progress. Attempts by one delegation to introduce a new open-ended concept of historic waters met widespread opposition.

Article 10, one of a number that takes account of new technological developments, provides that offshore installations and artificial islands shall not be considered as permanent harbour works for purposes of measuring the territorial sea; it is the logical companion of Article 48 (economic zone), which expands the scope of a similar rule in Article 5 of the Continental Shelf Convention and provides that artificial islands, installations, and structures have no territorial sea of their own and that their presence does not affect the delimitation of the territorial sea or other forms of coastal state jurisdiction.

A similar adaptation to change in the rules of innocent passage is effected in Article 22, also based on the work of an informal Committee II group. The article repeats the rule in Article 16(2) of the Territorial Sea Convention that the coastal state may take the steps necessary to prevent any breach of the conditions to which admission to internal waters is subject, but also extends it to "ships proceeding to . . . a call at a port facility outside internal waters."

11 15 UST 1606; TIAS No. 5639; 516 UNTS 205; 52 AJIL 851 (1958).

12 Id., Art. 14. 
passage prejudicial to the peace, good order, or security of the coastal state. ${ }^{13}$

The right of the coastal state to regulate innocent passage was not dealt with in detail in the Territorial Sea Convention. Article 18 of the single negotiating text elaborates the scope of this regulatory power and deals with both navigational safety and prevention of pollution; it also contains a proviso that coastal state laws and regulations "shall not apply to or affect the design, construction, manning or equipment of foreign ships or matters regulated by generally accepted international rules unless specifically authorized by such rules." This proviso is likely to be controversial. ! While the text of Article 20, paragraph 3 in the Committee III draft on Protection and Preservation of the Marine Environment is unclear, its intended effect is apparently to give the coastal state more regulatory latitude to adopt higher standards in the territorial sea, provided they do not hamper innocent passage. Article 21 of the territorial sea chapter, in addition to specifying that the coastal state shall not discriminate in form or in fact against the ships of any state or against ships carrying cargoes to, from, or on behalf of any state, provides that the coastal state shall not "hamper" innocent passage or "impose requirements on foreign ships which have the practical effect of denying or prejudicing the right of innocent passage." The complex nature of the problem of pollution regulation was widely recognized when a few states proposed the superficially enticing idea of stating that pollution is not innocent.

Article 23 provides that a ship that does not comply with coastal state "laws and regulations concerning navigation" shall be liable for any damage caused to the coastal state. It also provides for coastal state liability if it "acts in a manner contrary to the provisions of these articles and loss or damage results to any foreign ship exercising the right of innocent passage."

After some confusion, a distinction was made between the exercise of customs and fiscal jurisdiction over offshore installations and the rights associated with the traditional contiguous zone. ${ }^{14}$ Thus, both the Evensen text and the single negotiating text specify that the coastal state can establish customs, fiscal, immigration, and sanitary regulations with respect to installations under its jurisdiction throughout the economic zone. Nevertheless, a number of states continued to argue in favor of a traditional contiguous zone, directed at ships, extending somewhat beyond a 12-mile territorial sea, in which the coastal state may exercise the control necessary to prevent and punish infringement of its customs, fiscal, immigration, or sanitary regulations in its territory or territorial sea; others felt this was unnecessary. Article 33 would permit such a zone to extend up to 24

\footnotetext{
13 Those who recognize the humanitarian origins of the law of the sea of ancient times and its implicit "duty to rescue" are likely to welcome new textual confirmation in the rule that the list does not apply to specified activities "for the purpose of rendering assistance to persons, ships or aircraft in danger or distress."

1s See Territorial Sea Convention, note 11 supra, Art. 24.
} 
nautical miles from the baseline from which the breadth of the territorial sea is measured.

\section{Straits Used for International Navigation}

The importance of the straits issue to the overall negotiations has long been recognized. At Geneva, there was increased sensitivity to the need to assure passage of such straits and to avoid establishing a basis for arbitrary interference with such passage. For some time, moderates had been searching for a rational solution which was "neither free transit nor innocent passage." In other words, a solution which would accommodate both the interests in passage and the concerns of straits states regarding such problems as navigational safety and pollution. The single negotiating text, which drew upon the efforts of a group of moderates from all regions, reflects this trend.

A right of "transit passage" would be established for "straits which are used for international navigation between one area of the high seas or an exclusive economic zone and another area of the high seas or an exclusive economic zone," except where the strait is formed by an island of the coastal state and a high seas or economic zone route of similar convenience exists seaward of the island..$^{15}$ "Transit passage is the exercise in accordance with the provisions of this Part of the freedom of navigation and overflight solely for the purpose of continuous and expeditious transit of the strait. ..."16 Article 43 prohibits suspension of transit passage.

Virtually all of the remaining provisions deal with the concerns of strait states. Article 34 specifies that the regime of passage through straits "shall not in other respects affect the status of the waters forming such straits nor the exercise by the strait State of its sovereignty or jurisdiction over such waters. ..." Article 39 requires vessels and aircraft inter alia to proceed without delay through the strait; to refrain from the threat or use of force against a strait state in violation of the UN Charter; to refrain from any activities other than those incident to their normal modes of continuous and expeditious transit unless rendered necessary by force majeure or by distress; and to comply with applicable international safety and pollution regulations. Article 40 permits the straits state to designate and substitute sealanes and to prescribe traffic separation schemes after adoption of its proposals by the competent international organization, which "may adopt only such sealanes and separation schemes as may be agreed with the strait State."

Article 41 deals with perhaps the most sensitive problem: the regulatory rights of the strait state. It permits the strait state to make laws and regulations regarding transit passage relating to:

(a) the safety of navigation and the regulation of marine traffic as provided in article 40 ;

${ }^{15}$ SNT, PART II, Art. 38.

Ie Ibid. 
(b) the prevention of pollution, giving effect to applicable international regulations regarding the discharge of oil, oily wastes and other noxious substances in the strait;

(c) with respect to fishing vessels, the prevention of fishing, including the stowage of fishing gear;

(d) the taking on board or putting overboard of any commodity, currency or person in contravention of the customs, fiscal, immigration or sanitary regulations of the strait State.

It provides that such laws and regulations shall be nondiscriminatory, and shall not have "the practical effect of denying, hampering or impairing the right of transit passage." Foreign ships "shall comply with such laws and regulations." With respect to the question of remedies in cases where there is sovereign immunity, that is where warships, government noncommercial ships, and state aircraft are involved, the article provides that the flag state "shall be responsible for . . . loss or damage . . . to a strait State or other State in the vicinity of the strait" resulting from acts by such ships or aircraft contrary to the Convention or such coastal state laws and regulations.

Article 35 makes clear that the drawing of straight baselines in accordance with the rules provided for in the territorial sea chapter cannot alter passage rights in straits used for international navigation established in the treaty. This result should be obvious, as baselines have been drawn across navigational channels in very important straits, but the issue was the source of some confusion at Geneva. Since the article makes clear that the straits chapter does not affect other forms of internal waters and does not alter the "used for international navigation" test, it may be hoped that the concerns expressed have been allayed.

Article 44 applies the regime of nonsuspendable innocent passage, as in the Territorial Sea Convention, ${ }^{17}$ in straits used for international navigation other than those to which transit passage applies; such other straits include straits used for international navigation between an area of the high seas or economic zone and the territorial sea of a foreign state.

\section{The Economic Zone}

While foreshadowed by other developments in the past few decades, the economic zone is a new concept of critical importance. The articles that would establish a 200 -mile economic zone affect more interests of more states than any other aspect of the single negotiating text. They attempt to deal comprehensively with activities in an area that embraces perhaps $40 \%$ of the sea and in which most of the known hydrocarbons and commercial fisheries of the sea are found. Ships would have to navigate through the economic zone of a third state to communicate with a majority of coastal states in the world.

17 Territorial Sea Convention, note I1 supra, Art. 16(4). 
In terms of the actual negotiations, there can be no doubt that the fundamental characteristic of the zone is an accommodation between coastal state and other interests, with a different balance struck with respect to different types of activities in the zone. It is most coastal or "territorial" in its treatment of the sovereign rights of the coastal state over seabed resources of the zone; it is most free or "international" in its treatment of navigation, overflight, and similar uses. But even with respect to these activities, on the one hand, the coastal state sovereign rights are subject to duties designed to protect other uses ${ }^{18}$ and the marine environment, ${ }^{19}$ and, on the other hand, the freedoms of all states are subject to traditional high seas duties ${ }^{20}$ and environmental duties, ${ }^{21}$ as well as the duty to have "due regard to the rights and duties of the coastal State." ${ }^{23}$

The single negotiating text was influenced by the long negotiations that resulted in the "sixth revision" Evensen Group text. That group devoted the better part of its time to the economic zone at Caracas and Geneva, and between sessions. It included chiefs of delegation in their personal capacity from about 40 of the most active Committee II participants from all regions and interest groups.

One significant difference between the Evensen text and the single negotiating text is in Article 45, the "chapeau" which elaborates the rights of the coastal state in the zone.

Article 1, paragraph 1 of the Evensen Group sixth revision text reads as follows:

The coastal State has in an area beyond and adjacent to its territorial sea, known as the exclusive economic zone:

(a) Sovereign rights for the purpose of exploring and exploiting, conserving and managing the natural resources, whether renewable or non-renewable, of the seabed and subsoil and the superjacent waters;

(b) Jurisdiction with regard to other activities for the economic exploration and exploitation of the zone, such as the production of energy from the water, currents and winds;

(c) Jurisdiction as provided for in this Convention with regard to:

(i) the preservation of the marine environment,

(ii) scientific research,

(iii) the establishment and use of artificial islands, installations and similar structures, including customs, fiscal, health and immigration regulations pertaining thereto;

(d) Other rights and duties provided for in this Convention.

18 SNT, PART II, Arts. 45(2), 48.

${ }^{19}$ Id., Art. 68 (applicable within the 200-mile zone pursuant to Art. 62); see SNT,

PART III, Protection and Preservation of the Marine Environment, Arts. 4, 17, 41.

20 SNT, PART II, Art. 47(2).

21 See SNT, PART III, Protection and Preservation of the Marine Environment, Arts. $4,20,26,41$.

22 SNT, PART II, Art. 47(3). 
Unlike the Evensen text, Article 45 of the single negotiating text ${ }^{23}$ does not distinguish between statements that are intended to establish jurisdiction (e.g., the sovereign rights of the coastal state over resources) and statements that are intended mainly as a summary indication of rights elaborated elsewhere in the Convention (e.g., pollution and scientific research, which are within the mandate of Committee III). In particular, Article 45 omits the qualifying words "as provided for in this Convention" in describing coastal state jurisdiction with respect to preservation of the marine environment, scientific research, and installations, and characterizes scientific research jurisdiction as "exclusive." The effect of course is to prejudge the outcome of issues and, in particular, to imply comprehensive and unlimited subject-matter jurisdiction where this has not been agreed. At least where vessel-source pollution is concerned, even the implication is contrary to the general trend of the negotiations in favor of freedom of navigation and international standards.

Another significant difference is in Article 47. One of the most difficult aspects of the Evensen Group's negotiation was the achievement of balance between the duty of the coastal state to have due regard for navigation and other freedoms and the duty of states exercising those freedoms to have due regard for the rights of the coastal state. Article 47 upsets this balance, probably unintentionally, by providing that "States . . . shall comply with the laws and regulations enacted by the coastal State in conformity with the provisions of this Part and other rules of international law." The problem is that this clause appears, not in an article dealing with activities such as mining or fishing over which the coastal state will have regulatory and enforcement jurisdiction, but in the article dealing with navigation and other freedoms which are not in principle subject to coastal state jurisdiction. It will, it is hoped, be recognized that this is largely a drafting problem.

A third significant difference is that, aside from a cross-reference to the rights of the coastal state over scientific research, to be elaborated in the chapters on that subject, the Evensen text does not deal with the issue. Article 49 of the single negotiating text addresses the issue ${ }^{24}$ and, by providing for coastal state consent for "any research concerning the economic

${ }^{29}$ Article 45 reads in pertinent part as follows:

1. In an area beyond and adjacent to its territorial sea, described as the exclusive economic zone, the coastal State has:

(a) sovereign rights for the purpose of exploring and exploiting, conserving and managing the natural resources, whether renewable or non-renewable, of the bed and subsoil and the superjacent waters;

(b) exclusive rights and jurisdiction with regard to the establishment and use of artificial islands, installations and structures;

(c) exclusive jurisdiction with regard to:

(i) other activities for the economic exploitation and exploration of the zone, such as the production of energy from the water, currents and winds; and

(ii) scientific research;

(d) jurisdiction with regard to the preservation of the marine environment, including pollution control and abatement;

(e) other rights and duties provided for in the present Convention.

24 Article 71 applies the Article 49 rule mutatis mutandis to research concerning the continental shelf and undertaken there. 
zone and undertaken there," clearly prejudges the main scientific research issue under negotiation in the Third Committee.

With respect to artificial islands and installations, Article 48, paragraph 1 of the single negotiating text provides:

In the exclusive economic zone, the coastal state shall have the exclusive right to construct and to authorize and regulate the construction, operation and use of:

(a) artificial islands;

(b) installations and structures for the purposes provided for in article 45 and other economic purposes;

(c) installations and structures which may interfere with the exercise of the rights of the coastal State in the zone.

This issue has undergone a very long period of difficult discussion in the Evensen Group and elsewhere. The text is an attempt to bridge the gap between those that wished to maintain the strict economic-noneconomic distinction inherent in the zone and those that did not by resolving the accommodation of conflicting uses problem in favor of the coastal state. It is clear that all artificial islands and all resource and other economic offshore installations (e.g., artificial deep water ports) are ipso facto subject to coastal state exclusive rights; however, it is equally clear that the "may interfere" test in subparagraph (c) "tilts" heavily toward the coastal state even with respect to noneconomic installations in the economic zone. It should also be noted that Article 67 gives the coastal state "the exclusive right to authorize and regulate drilling on the continental shelf for all purposes"; the Article 62 definition of the continental shelf includes the full 200-mile zone. While arms control questions are beyond the scope of the Law of the Sea Conference, the provisions and prohibitions of the Seabed Arms Control Treaty ${ }^{25}$ are of course also relevant; its parties include the United Kingdom, United States, and U.S.S.R.

The question of the juridical status and the rights enjoyed by all states in the economic zone was one of the most difficult aspects of the negotiations. The single negotiating text reflects the clear consensus in favor of "the freedoms of navigation and overflight and of the laying of submarine cables and pipelines and other internationally lawful uses of the sea related to navigation and communication," ${ }^{28}$ on the one hand, and coastal state "sovereign rights for the purpose of exploring and exploiting, conserving and managing the natural resources, whether renewable or non-renewable," ${ }^{27}$ on the other hand. The problem centered on the "residual rights" which the Convention does not attribute either to the coastal state or to all states. This is linked to the question whether the status of the economic

25 Treaty on the Prohibition of the Emplacement of Nuclear Weapons and other Weapons of Mass Destruction on the Seabed and the Ocean Floor and in the Subsoil thereof, 23 UST 701, TIAS No. 7337 (1971). The treaty entered into force in 1972 and will, by its terms, be reviewed in 1977.

26 SNT, PART II, Art. 47(1).

${ }^{27}$ Id., Art. 45(I)(a). 
zone is high seas (without prejudice, of course, to the specified rights of the coastal state in the zone).

The solution proposed in the single negotiating text has a number of elements. On the one hand, Article 73 defines the "high seas" as excluding the economic zone, reflecting the often expressed view that the zone is neither territorial sea nor high seas, but sui generis. On the other hand, it attempts to reflect the view that the economic zone does not alter in concept the exercise of high seas freedoms being preserved. Article 47 incorporates by reference most of the articles of the high seas chapter (excluding the definition of the high seas, the enumeration of high seas freedoms, and fishing provisions) and other pertinent rules of international law "in so far as they are not incompatible with the provisions of this Part."

With respect to the residuum, Article 47(3) provides:

In cases where the present Convention does not attribute rights or jurisdiction to the coastal State or to other States within the exclusive economic zone, and a conflict arises between the interests of the coastal State and any other State or States, the conflict should be resolved on the basis of equity and in the light of all the relevant circumstances, taking into account the respective importance of the interests involved to the parties as well as to the international community as a whole.

The exclusion of the economic zone from the definition of the high seas was strongly opposed by some states.

The basic thrust of the economic zone is, of course, resource jurisdiction. Its most "revolutionary" aspect is the elimination of freedom of fishing and the substitution of coastal state sovereign rights over the exploration, exploitation, conservation, and management of living resources. Such a drastic alteration, coupled with the problems associated with the migratory and other biological characteristics of fish stocks, necessarily raises a number of practical problems that require resolution if a sound and widely acceptable agreement is to be reached. Therefore, it is not surprising that most of the articles in the economic zone section deal with fishing.

There are six basic elements in the treatment of fisheries in the single negotiating text:

(1) The "sovereign rights" of the coastal state. ${ }^{28}$ Fishing is subject to the jurisdiction and broad regulatory, and management powers of the coastal state. ${ }^{20}$

(2) The coastal state duty to conserve. It has the duty to determine the allowable catch and adopt other conservation measures "designed to maintain or restore populations of harvested species at levels which can produce the maximum sustainable yield, as qualified by relevant environmental and economic factors"; to ensure "that the maintenance of the living resources . . . is not endangered by over-exploitation"; and "to take into consideration the effects on species associated with or dependent upon harvested species." 30

28 Ibid.

20 Id., Arts. 50, 51.

so Id., Art. 50. 
(3) The coastal state priority allocation and duty to ensure optimum utilization. It has the duty to "determine its capacity to harvest the living resources" of the zone and, where it "does not have the capacity to harvest the entire allowable catch," to "give other States access to the surplus of the allowable catch" pursuant to coastal state regulations "consistent with the provisions of the present Convention." Among the factors the coastal state "shall take into account" in granting such access is "the need to minimize economic dislocation in States whose nationals have habitually fished in the zone or which have made substantial efforts in research and identification of stocks." s1

(4) Special provisions for highly migratory species, ${ }^{\mathbf{2 2}}$ anadromous species, ${ }^{33}$ catadromous species, ${ }^{\mathbf{3 4}}$ marine mammals, ${ }^{35}$ and sedentary species. ${ }^{35}$

(5) Special provisions regarding access of landlocked and "geographically disadvantaged" states to fisheries in the economic zone of their neighbors. ${ }^{37}$ These states publicly indicated their disagreement with the Evensen text and the Group of 77 text on the grounds that the access rights were insufficient.

(6) Comprehensive fisheries enforcement rights for coastal states in the zone. These include "boarding, inspection, arrest, and judicial pro-

82 Id., Art. 51.

82 Id., Art. 53. With respect to enumerated highly migratory species such as tuna, the coastal state and other states whose nationals fish such species in the region are required to "co-operate directly or through appropriate international organizations with a view to ensuring conservation and promoting the objective of optimum utilization of such species throughout the region, both within and beyond the exclusive economic zone." The Evensen sixth revision text does not contain a precise proposed article on highly migratory species, which could not be completed due to continuing differences.

${ }^{33}$ Id., Art. 54. With respect to anadromous species such as salmon, the states "in whose rivers anadromous stocks originate shall have the primary interest in and responsibility for such stocks," may establish total allowable catches, regulate fishing for such stocks within their economic zones and beyond economic zones of other states, and have the duty to cooperate in minimizing economic dislocation in other states fishing these stocks, which is the only exception to the rule that fishing for anadromous stocks "shall be conducted only in waters within exclusive economic zones" (a reference intended in the Evensen text to embrace territorial and internal waters as well). With respect to anadromous stocks migrating through their economic zones, other states must "cooperate with the State of origin with regard to the conservation and management of such stocks."

34 Id., Art. 55. With respect to catadromous species such as eels, there is a provision giving special rights to the "coastal State in whose waters catadromous species spend the greater part of their life cycle."

85 Id., Art. 53(3).

Nothing in the present Convention shall restrict the right of a coastal State or international organization, as appropriate, to prohibit, regulate and limit the exploitation of marine mammals. States shall co-operate either directly or through appropriate international organizations with a view to the protection and management of marine mammals.

s6 Id., Art. 56. This article excludes sedentary species of the continental shelf from the application of the economic zone chapter, thus leaving the sovereign rights of coastal states under Article 63 unqualified by the economic zone duties.

${ }^{87}$ Id., Arts. 57-59; see also Art. 51(3). 
ceedings," provided that arrested vessels and their crews "shall be promptly released upon the posting of reasonable bond or other security" and that "penalties for violations of fisheries regulations may not include imprisonment" in the absence of agreement to the contrary. ${ }^{83}$

The nature of the provisions regarding highly migratory species and the provisions regarding access of landlocked and "geographically disadvantaged" states were very controversial issues in Geneva and will probably be the focus of attention on fisheries issues during intersessional consultations.

The question of the delimitation of the economic zone and the continental shelf between neighboring coastal states is a highly divisive one which, in the last analysis, is essentially bilateral in character. The interest of the community in general is in providing a legal basis for the peaceful resolution of the problem by the neighboring states concerned. This can be achieved through the elaboration of general substantive rules, procedures, or both. ${ }^{99}$

The approach to delimitation issues in the 1958 Continental Shelf Convention is to lay down the "equidistance/special circumstances" rule and leave the matter to bilateral negotiation. ${ }^{40}$ While a different rule is enunciated in the North Sea Continental Shelf cases, that judgment (necessarily limited by the terms on which the case was submitted) is also primarily concerned with substance.41 At present, whatever the merits of their arguments, it is clear that some states are relying on the special circumstances exception in the Continental Shelf Convention, the North Sea Continental Shelfs cases judgment, or both, as a basis for opposing the automatic application of the equidistance principle. There are widely varying views on both the substance and application of international law on the issue.

s8 Id., Art. 60.

${ }^{39}$ Where fisheries are concerned, delimitation is not the only issue. There is an obvious need to agree upon coordinated conservation and allocation measures for stocks which migrate across national limits; Article 52 confirms this need. To some extent, similar considerations are relevant in the case of fluid nonliving resources.

40 Convention on the Continental Shelf; 15 UST 471; TIAS No. 5578; 499 UNTS 311; 52 AJIL 858 (1958). Art. 6.

$\$ 1$ North Sea Continental Shelf, Judgment, [1969] ICJ REP. 3, (Special Agreements submitting the cases at 7-8; findings at 53-54). The Special Agreements submitting the cases requested the Court to decide what "principles and rules of international law are applicable to the delimitation" as between the parties, specifying that the parties would "delimit the continental shelf in the North Sea as between their countries by agreement in pursuance of the decision requested" from the Court. The Court decided that the equidistance rule was not opposable to the Federal Republic of Germany, which was not a party to the Continental Shelf Convention; found that there is "no other single method of delimitation the use of which is in all circumstances obligatory"; and elaborated substantive criteria based on a theory of "natural prolongation" to be applied by the Federal Republic, Denmark, and the Netherlands in delimiting "by agreement" their respective areas of jurisdiction. SNT Article 61(1) draws upon that part of paragraph $C(I)$ of the Judgment which states, "delimitation is to be effected by agreement in accordance with equitable principles, and taking into account all of the relevant circumstances," omits the substantive geographic qualifications and criteria in the Judgment, but adds the language, "employing, where appropriate, the median or equidistance line." 
Article 61 and the essentially identical Article 70 regarding the continental shelf place primary emphasis on procedure; they emphasize the community interest in keeping the peace. Article 61 provides in pertinent part:

(1) The delimitation of the exclusive economic zone between adjacent or opposite States shall be effected by agreement in accordance with equitable principles, employing, where appropriate, the median or equidistance line, and taking account of all the relevant circumstances.

(2) If no agreement can be reached within a reasonable period of time, the States concerned shall resort to the procedures provided for in Part... (settlement of disputes).

(3) Pending agreement, no State is entitled to extend its exclusive economic zone beyond the median line or the equidistance line.

The viability of paragraph 3 as an interim rule is largely dependent upon the right of a state to resort to compulsory dispute settlement under paragraph 2 to determine that "a reasonable period of time" has elapsed and to resolve the issue; otherwise the party that prefers the median or equidistant line could simply refuse to agree on another line. In effect, the two paragraphs largely relieve the pressure on states to take potentially conflicting steps in disputed areas in order to protect their claims. It is not clear what the reaction to this imaginative new approach will be. There was some opposition in the Dispute Settlement Group to compulsory dispute settlement of maritime boundaries between neighboring states. ${ }^{42}$ Since boundary disputes can be among the most dangerous, the substantial contribution that the procedural ideas underlying draft Articles 61 and 70 could make to avoiding such dangers should be carefully weighed.

The differences in the negotiations over the entitlement of small islands to an economic zone and continental shelf are, in practical terms, closely linked to the delimitation problem. No specific reference is made to islands in the articles on delimitation. The issue would presumbaly be raised under the reference to "equitable principles" and "all the relevant circumstances" in Articles 61 and 70. However, Article 132 of the single negotiating text provides, "Rocks which cannot sustain human habitation or economic life of their own shall have no exclusive economic zone or continental shelf."

\section{The Continental Shelf}

The basic and still unresolved issue regarding the continental shelf is whether it would be defined to include continental margin areas beyond 200 miles, thereby placing seabed resource exploration and exploitation of the entire margin under coastal state jurisdiction.

22 Annex I, Art. 17(3) (b) of the dispute settlement group text and SNT (Settlement of Disputes) Art. 18(2)(b), note 3 supra, contain a qualified exception to the compulsory procedures in this connection. 
Articles 62 and 69 reflect the view of many moderates that an accommodation which combines coastal state jurisdiction and a revenue-sharing obligation with respect to mineral exploitation of the margin beyond 200-miles is the only practical way to protect the general interest in widespread agreement. There was widespread opposition to revenue sharing with respect to areas within 200 miles.

In response to the concerns of a number of states that the outer edge of the margin be precisely defined, work is continuing in the Evensen Group on a more precise definition that might incorporate review by an international commission, which would certify the result to the coastal state and the international Authority for the seabed.

Article 69 does not specify the amount of revenue sharing, but does reflect the view of the United States and others that the obligation should be stated as a percentage of the value of mineral production at the site in order to ensure greater simplicity and certainty of expectations. It also reflects the view of some countries that the coastal state might, if it wishes, make its contribution in kind as a percentage of the "volume of production" at the site. Some states with broad margins argued that a system of profit sharing would be more feasible, as it would take account of the need to recover the costs of the large investments likely to be required for production in deep areas that are far from shore prior to making any fixed payments to the international community. However, supporters of a formula based on a percentage of the value of production noted the diffculties in determining profits on a uniform and equitable basis under different economic, accounting, and tax systems.

In order to illustrate how a system of contributions might work and might accommodate in some measure the views of those advocating profit sharing, the United States informally presented a specific idea with respect to revenue sharing from the area beyond 200 miles, based on an increasing percentage of the value of production at the site. ${ }^{43}$

Article 69 also provides for the international Authority to determine the extent of developing country revenue-sharing obligations. Some states, including the United States, have indicated that they can support discrimination in the distribution of these funds in favor of developing countries, but not discriminatory contribution rates. It is, after all, the rate and value of production that would determine the contribution. The underlying accommodation that revenue sharing represents is that, in exchange for agreeing to coastal state jurisdiction to the outer edge of the margin, the international community would receive a share of the benefits of mineral

\footnotetext{
18 After five years of production at a site, the coastal state's obligation to share revenues would begin at one percent of wellhead value, and thereafter increase by one percent per year until it reached five percent in the tenth year, after which it would remain at five percent. Experts on the U.S. Delegation calculated that for a field producing 700 million barrels of oil through a 20 -year depletion period, assuming a value of $\$ 11$ per barrel, the total amount of the revenue sharing would be $\$ 130$ million. The oil and other minerals themselves, and additional revenues collected by the coastal state, would of course remain with the coastal state.
} 
exploitation. Very few developing coastal states are likely to be affected to a significant degree. The acceptability of this basis of accommodation on the margin issue would be jeopardized by injecting the broad philosophical and political difficulties inherent in discriminatory rates of contribution. Perhaps one way around the problem might be to allow some coastal state flexibility as to the development organizations receiving contributions, which might include regional development organizations associated with the United Nations.

The questions of drilling, scientific research on the continental shelf, sedentary species, and delimitation between opposite and adjacent states were discussed in connection with the economic zone. While Article 66 would treat installations on the continental shelf beyond the economic zone in the same manner as those within the zone, there was sentiment for taking, with respect to the area beyond 200 miles, the approach of Article 5 of the 1958 Continental Shelf Convention, which refers to coastal state jurisdiction only in respect of installations for the exploration and exploitation of the natural resources of the continental shelf.

\section{The High Seas}

The most important question raised by the high seas chapter is the definition of the high seas. The implications of defining the high seas to exclude the economic zone have been discussed in connection with the economic zone.

Informal consultations on the high seas held by Committee II were very productive. While the questions of the definition of the high seas, high seas freedoms, and living resources were deferred pending consideration of the economic zone, single draft texts on which the single negotiating text is based were prepared by the participants. These texts are largely derived from the existing high seas regime as codified in the 1958 High Seas Convention, ${ }^{44}$ with some elaborations. ${ }^{45}$

Articles 103 and 101, taken together, make it clear that freedom of fishing on the high seas beyond the economic zone is "subject to ... the duty to adopt, or to cooperate with other States in adopting, such measures for their respective nationals as may be necessary for the conservation of the living

4 Convention on the High Seas; 13 UST 2312; TIAS No. 5200; 450 UNTS 82; 52 AJIL 842 (1958).

45 Notable elaborations are contained in Article 80, which develops the obligations of the flag state with respect to ships flying its flag; Article 94, which provides for international cooperation in the suppression of illicit traffic in narcotic drugs and psychotropic substances; Article 95, which subjects any person engaged in "unauthorized broadcasting" on the high seas to arrest and prosecution, inter alia, by a state "where the transmissions can be received or ... where radio communication is suffering interference"; Article 97, which applies the coastal state right of hot pursuit to violations of applicable coastal state laws and regulations in the economic zone or on the continental shelf, including safety zones around continental shelf installations; and Article 100, which expands the obligation of flag states to ensure that their vessels do not break or injure submarine cables and pipelines. 
resources of the high seas." In addition, where the same stock or stocks of associated species occur both within the economic zone and "in an area beyond and adjacent to the zone," Article 52(2) provides for the coastal state and states fishing such stocks in the adjacent area to seek to agree on conservation measures in the adjacent area. While this provision does not speak of a "special interest" of the coastal state in conservation, its practical effect, particularly if there is compulsory dispute settlement, would be to provide some protection of the conservation interests of the coastal state. The special treatment for certain types of species is elaborated in the economic zone and continental shelf articles. ${ }^{46}$

\section{Landlocked States}

Article 109 provides that landlocked states "shall have the right of access to and from the sea for the purpose of exercising the rights provided for in the present Convention." Terms and conditions would be specified in bilateral, subregional, or regional agreements. Transit states "have the right to take all measures to ensure that the rights provided for in this Part shall in no way infringe their legitimate interests." Traffic in transit would be exempt from customs duties, taxes, and charges other than those for specific services rendered."

The importance of the issue of access to and from the sea is related not only to the increased number of landlocked states in the international community, particularly in Africa, but to the fact that the means and commercial incentives in developing coastal states for transporting the trade of developing landlocked states may not be entirely equal to the need. ${ }^{48}$

Landlocked states are understandably concerned about ensuring that their rights are unambiguous. Transit states are understandably concerned about assuming treaty obligations they would have difficulty meeting. Negotiations on this issue in Geneva were difficult, although there was broad agreement on the need to provide access to the sea for landlocked states; with one or two exceptions, there was no evidence of resistance in principle to a clear right of access. African coastal and landlocked states are the most broadly affected; it is notable that they have shown considerable sensitivity and statesmanship on this issue.

\section{Archipelagos}

The single negotiating text seeks to accommodate the desire of certain island nations to enclose the waters of their archipelagos with the interests of other nations in protecting the seas from unreasonably broad claims and in protecting navigation and overflight.

46 See notes 32-36, supra.

17 SNT, Part II, Art. 111.

48 "Transit States may request the land-locked States concerned to co-operate in constructing or improving" means of transport to give effect to the right of access. Id., Art. 113. 
Article 117 provides that "archipelagic State' means a State constituted wholly by one or more archipelagos and may include other islands." The concept does not apply to islands of continental states. There was strong opposition to any such extension of the concept. The purpose of Article 1:31, which says the archipelago provisions are "without prejudice to the status of oceanic archipelagos forming an integral part of the territory of a continental State," is unclear.

The articles establish criteria in terms of length of line and land-to-water ratio for drawing lines around an island group..9 Waters within such lines are "archipelagic waters" where the archipelagic state exercises sovereignty "subject to the provisions of this section." so The territorial sea, contiguous zone, economic zone, and continental shelf would be measured seaward of these lines. ${ }^{\text {s1 }}$

Article 124 establishes a right of "archipelagic sealanes passage" in sealanes and air routes designated by the archipelagic state "suitable for the safe, continuous and expeditious passage of foreign ships and aircraft" through archipelagic waters. Criteria for the width and location of lanes are elaborated. Article 124(3) defines archipelagic sealanes passage as follows:

Archipelagic sealanes passage is the exercise in accordance with the provisions of the present Convention of the rights of navigation and overflight in the normal mode for the purpose of continuous and expeditious transit through an archipelago between one part of the high seas or an exclusive economic zone and another part of the high seas or an exclusive economic zone.

The provisions regarding the duties of states exercising the right of archipelagic sealanes passage, ${ }^{52}$ the designation and international review of sealanes and traffic separation schemes, ${ }^{53}$ and the regulatory rights of the archipelagic states with respect to such passage ${ }^{54}$ are similar to the provisions regarding transit passage of straits.

In archipelagic waters outside sealanes and air routes, there would be a right of innocent passage subject to temporary and nondiscriminatory suspension by the archipelagic state where essential for the protection of its security..$^{\text {s5 }}$ There are also special provisions regarding traditional fishing rights ${ }^{58}$ and communication between two parts of the territory ${ }^{87}$ of an immediately adjacent neighboring state.

The question of archipelagos is a good example of the delicate problem of promoting a widely acceptable treaty. Inclusion of the concept is of overriding concern to a limited number of states. However, unless the definition is carefully circumscribed and adequate navigation and overflight rights are guaranteed, inclusion of the concept would seriously reduce the chances of a widely acceptable treaty.

\footnotetext{
19 Id., Art. 118.

11 I., Art. 119.

33 Id., Art. 124.

ss Id., Art. 123.

${ }^{57}$ Id., Art. 118(7).
}

s0 Id., Art. 120.
82.Id., Art. 125.
s4 Id., Art. 128.
is Id., Art. 122. 


\section{Regime of Islands}

As noted before, Article 132 of the single negotiating text provides that "rocks which cannot sustain human habitation or economic life of their own shall have no exclusive economic zone or continental shelf." Aside from this, all the substantive rules of the Convention applicable to other land territory also apply to an island, defined as a "naturally formed area of land, surrounded by water, which is above water at high tide."

The effect of this text, and the reactions of states to it, are unclear. For example, what if it is the presence of marine resources and the desalination of sea water that render habitation and economic life possible? ${ }^{88}$

\section{Enclosed and Semienclosed Seas}

Article 134 provides for cooperation among states bordering enclosed or semienclosed seas in the exercise of their rights and duties under the Convention. Specific reference is made in this regard to coordination with respect to living resources, preservation of the marine environment, and scientific research. Article 135 makes clear that these provisions do not affect the rights and duties of coastal or other states under other provisions of the Convention.

Article 134 is perhaps a somewhat narrower example of the general need for cooperation among neighboring coastal states. It does, however, tend to reflect some efforts already underway or under consideration in such areas as the North Sea, the Mediterranean Sea, the Caribbean Sea, and the Persian Gulf.

\section{Territories Under Foreign Occupation or Colonial Domination}

The very heading "territories under foreign occupation or colonial domination" suggests political issues more suitable for discussion in the political organs of the United Nations than in connection with a Convention on the Law of the Sea. The main thrust of Article 136 is to vest offshore resource rights under the Convention in the inhabitants of territories under foreign occupation or colonial domination, a UN Trust Territory, or a territory administered by the UN, "to be exercised by them for their own benefit."

There are few aspects of Article 136 that would be susceptible of interpretation without reference to a particular political point of view. For example, where "a dispute over the sovereignty of a territory under foreign occupation or colonial domination exists," coastal state resource rights "shall

s8 On a more technical level, since even low tide elevations along the coast can bo used for establishing baselines under some circumstances (see Arts. 4 and 12), Article 132 arguably should not affect the use of rocks in such situations. Moreover, the relationship to the archipelago articles is unclear; surely, encouraging governments whose populations are dependent on the resources around small islands to seek to resolve their problem through expansion of the archipelago concept would have exactly the opposite effect of that intended by Article 132, and could further complicate the already uncertain situation regarding the ultimate acceptability of an archipelago concopt. 
not be exercised until such dispute is settled in accordance with the purposes and principles of the Charter of the United Nations." It would seem that, when there is a sovereignty dispute, the disputed area in question would normally be regarded by the claimant state that does not actually control the area as being "under foreign occupation," if not "colonial domination." Do the inhabitants benefit by this? Might third states benefit?

It is perhaps useful to remember that the original stimulus for this article was the significant persistence of colonialism in Africa. That is now changing rapidly. It is also useful to remember that freedom of choice is now the rule, not the exception, applied by former colonial powers to their remaining dependencies. In some cases, these dependencies have clearly indicated a preference to maintain that status; in others, the process is now developing; in still others, the United Nations itself has authorized the non-self-governing relationship. In all these situations, a state cannot assume treaty obligations and then hope that the inhabitants of a dependency will, in the exercise of rights, ensure that the obligations are met. Moreover, precisely how can these inhabitants deal with foreign powers that might encroach upon those rights, if the presumably more powerful "metropolitan" power is prohibited from exercising the rights?

For Americans, particularly as we enter our bicentennial year, the anticolonial sentiments of Article 136 strike a responsive chord. For many countries of the world, those sentiments were until recently fundamental to their national aspirations and not merely their foreign policies. But the fact remains that, if a state is in illegal control of territory or violating the international rules applicable to the administration of an area and the protection of its inhabitants, the issue is broader than offshore resource jurisdiction and should be dealt with directly in the appropriate forum. No state will normally concede that it is illegally occupying territory. A Law of the Sea Convention cannot resolve the problem; it can create confusion that, as a careful analysis of the potential effects of Article 136 will reveal, could provide a juridical or practical windfall to third states and accordingly reduce their interest in encouraging a just alteration in the situation.

\section{Settlement of Disputes}

Article 137 contains a general cross-reference to the application of the provisions of the dispute-settlement chapter of the Convention. This is a necessary aspect of any settlement of Committee II issues.

\section{The Third Committee}

\section{Protection and Presercation of the Marine Environment}

The single negotiating text on protection and preservation of the marine environment largely reflects the results achieved in Caracas on the general articles on the subject and the specific results in the Working Group on 
marine pollution in Geneva with respect to monitoring, environmental assessment, landbased pollution, ocean dumping, and pollution from continental shelf activities. In some of these fields such work was not fully completed. The Evensen Group concentrated on the problem of vesselsource pollution, which was not resolved, although a clear trend against coastal state standard setting in the economic zone is reflected in the single negotiating text.

The first chapter, General Provisions, sets out the basic legal obligations to protect and preserve the marine environment and addresses the difficult and controversial problem of balancing these obligations against economic considerations and legitimate uses of the sea. These articles provide in part:

States have the obligation to protect and preserve all the marine environment. 5 ?

States have the sovereign right to exploit their natural resources pursuant to their environmental policies and they shall, in accordance with their duty to protect and preserve the marine environment, take into account their economic needs and their programmes for economic development. ${ }^{60}$

States shall take all necessary measures consistent with this Convention to prevent, reduce and control pollution of the marine environment from any source using for this purpose the best practicable means at their disposal and in accordance with their capabilities, individually or jointly, as appropriate, and they shall endeavour to harmonize their policies in this connexion. ${ }^{61}$

States shall take all necessary measures to ensure that marine pollution does not spread outside their national jurisdiction and that activities under their jurisdiction or control are so conducted that they do not cause damage by pollution to other States and their environment, nor cause pollution beyond the areas where States exercise sovereign rights in accordance with this Convention. ${ }^{62}$

The measures taken pursuant to these articles shall deal with all sources whatsoever of pollution of the marine environment ... In taking measures to prevent pollution of the marine environment States shall have due regard to the legitimate uses of the marine environment, which are not incompatible with the provisions of this Convention and shall refrain from unjustifiable interference with such uses. ${ }^{63}$

The second chapter sets out obligations to formulate and elaborate international rules, standards, and recommended practices and procedures for the prevention of pollution; ${ }^{64}$ to cooperate in eliminating the effects of pollution and preventing or minimizing damage, ${ }^{65}$ and to cooperate in scientific research and data exchange programs regarding pollution and

so SNT, PART III, Protection and Preservation of the Marine Environment, Art. 2.

${ }^{\circ 0}$ Id., Art. 3.

${ }^{61}$ Id., Art. 4.

62 Ibid.

os Ibid.

os Id., Art. 6.

Bs Id., Art. 8. 
its remedies ${ }^{68}$ and in working out appropriate scientific criteria for the formulation of international environmental measures. ${ }^{67}$

Chapter Three contains broad provisions on the promotion of scientific, educational, technical, and other assistance to developing countries for the preservation of the marine environment and the prevention of pollution. Such provisions can and should be regarded as an integral part of a global effort to control marine pollution.

Chapter Four obliges states to "endeavour, as much as is practicable" to monitor pollution of the marine environment, and to report the results to the UN Environment Programme or any other competent organization, "which should make them available to all States." While the qualifying language is, at least in tone, regrettable, it is notable that states are also required to keep under surveillance "the effect of any activities which they permit or in which they engage to determine whether these are likely to pollute the marine environment."

Chapter Five provides that States "shall, as far as practicable, assess the potential effects of [planned] activities on the marine environment" where there are "reasonable grounds for expecting that [they] may cause substantial pollution of the marine environment," and report the results of such assessments. This is a good illustration of how a legal development on a national level, in this case the requirement for environmental impact statements in U.S. law, ${ }^{68}$ can inspire a parallel development on the international level.

Chapter Six, regarding standards to prevent, reduce, and control marine pollution raises perhaps the most difficult issue in this section. It provides that states "shall establish . . . international rules and standards" regarding vessel-source pollution; ${ }^{69}$ "shall establish global and regional rules, standards and recommended practices and procedures" regarding pollution from exploration and exploitation of the seabed (continental shelf) and "from installations under their jurisdiction"; ${ }^{70}$ "shall endeavour to establish" as soon as possible such global and regional measures regarding ocean dumping; ${ }^{\text {"1 }}$ and "shall endeavour to establish" such global and regional measures regarding pollution from atmospheric sources ${ }^{2}$ and "from landbased sources, taking into account characteristic regional features, the economic capacity of developing countries and their need for economic development." 73

In the case of pollution from landbased and atmospheric sources, states are required to establish national laws and regulations, "taking into account internationally agreed rules, standards and recommended practices and procedures." For all sources of marine pollution except landbased and

${ }^{86}$ Id., Art. 9.

${ }^{88}$ National Environmental Policy Act of 1969, sec. 102; 83 Stat. 853; 42 U.S.C. 4332.

${ }^{69}$ SNT, PART III, Protection and Preservation of the Marine Environment, Art. 20.

70 Id., Art. 17; see also SNT, PART II, Art. 68.

71 Id., Art. 19.

72 Id., Art. 21.

13 Id., Art. 16. 
atmospheric sources, there is a requirement that national laws and regulations "shall be no less effective" than international or generally accepted rules and standards; with respect to these sources of marine pollution, the text also applies the "no less effective" rule to internationally "recommended practices and procedures," although questions were raised in Geneva as to the appropriateness of applying the rule to recommendations.

The general approach of these articles is to vest the relevant environmental rights and duties in that state which has jurisdiction over the activity in question. The close relationship between the application of environmental measures and the overall regulation of activities justifies such an approach. There would be the possibility of interference should another state be granted such rights and duties. Thus, a coastal state, with respect to seabed exploitation in its economic zone, and a flag state, with respect to vessels flying its flag, would be obliged to carry out the relevant environmental duties and would have the right to impose more stringent environmental measures than those required by the duty to respect international standards. On the other hand, the duty to develop and respect international standards derives from a recognition of the fact that the state whose activities are the source of pollution is not necessarily the only state affected by such pollution; in some cases, it may not even be the most affected. This is an additional reason for the strong and widespread support for international standards with respect to vessel-source pollution.

Three exceptions to this jurisdictional approach to environmental standards for vessel-source pollution are suggested in Articles 19 and 20 of the single negotiating text:

(1) Dumping of wastes and other matter within a zone of as yet unspecified distance from the coast would require the express approval of the coastal state. ${ }^{74}$ It can be argued that dumping is not in essence vesselsource pollution but landbased pollution transported to sea, as the issue of normal vessel operations does not basically arise.

(2) While the language is unclear, it appears that the coastal state would be permitted to establish "more effective" standards for vessel-source pollution in its territorial sea provided they do not have the practical effect of hampering innocent passage..$^{75}$ There is an apparent inconsistency of intent with Article 18 in the Committee II text, which would exclude ship design, construction, manning, and equipment from coastal state regulation.

(3) Article 20(5) provides:

Nothing in this Article shall be deemed to affect the establishment by the coastal State of appropriate non-discriminatory laws and regulations for the protection of the marine environment in areas within the economic zone, where particularly severe climatic conditions create obstructions or exceptional hazards to navigation, and where pollution of the marine environment, according to accepted scientific criteria, could cause major harm to or irreversible disturbance of the ecological balance.

7* Id., Art. 19(3).

7s 1d., Art. 20(3). 
Article 20, paragraphs 4 and 6, also contain a procedure for the coastal state to obtain international recognition in the competent international organization for the designation of a "special area" of the economic zone in which the adoption of special mandatory measures for the prevention of pollution from vessels is required. Although the language is somewhwat unclear, it would appear that this is intended as a reference to the international adoption of special discharge rules in "special areas" along the lines of the 1973 Marine Pollution Convention, where the term "special area" is used as a term of art. ${ }^{76}$

It must be recognized that freedom of navigation in the economic zone is affected by coastal state rights with respect to vessel-source pollution; this is particularly true with respect to the establishment of standards. International establishment of standards not only protects environmentally affected states, it also protects economically affected states. There has been, and can be, international agreement on the establishment and content of special standards for particular areas where necessary. However, there is no assurance that the appropriate balance of interests will be reflected in a unilateral coastal state decision on such standards, for example as contemplated by Article 20(5).

While the general approach of relying on the state conducting the activity to enforce international standards is reflected in Chapter Seven, both juridical and practical questions arise with respect to vessels.

The juridical problems involved in limiting enforcement of vessel-source pollution laws and regulations to the flag state relate to the rights of the coastal state in ports and in the territorial sea. A state has the right to establish conditions of entry to its ports. ${ }^{77}$ In addition, the coastal state is sovereign, subject to its duty to respect innocent passage, in its territorial sea. It has certain regulatory rights with respect to innocent passage. ${ }^{78}$

The practical problem relates to the difficulty of ensuring direct environmental supervision by a flag state over its vessels around the world. Thus, certain special enforcement provisions are contemplated in the single negotiating text.

First, the duty of the flag state to investigate violations "at the documented request of any State," to bring proceedings, and to impose adequate penalties "regardless of where violations occurred" is emphasized. ${ }^{79}$

Secondly, given the fact that pollution enforcement with respect to a vessel voluntarily in a port does not entail the dangers or practical diffculties of foreign actions against a vessel at sea, substantial enforcement rights and duties for the port state are contemplated. These include a duty

76 International Convention for the Prevention of Pollution from Ships, 1973, IMCO Doc. MP/CONF./WP.35, Nov. 2, 1973 (not yet in force); 12 ILM 1319 (1973).

77 See Territorial Sea Convention, note 11 supra, Art. 16; SNT, PART II, Art. 22(2). The 1973 Marine Pollution Convention, note 76 supra, refers to specified enforcement actions by the port state in Articles 5 and 6.

78 Territorial Sea Convention, note 11 supra, Arts. 1, 14, 17; see SNT, PART II, Arts. $1,14,18$.

70 SNT, PARt III, Protection and Preservation of the Marine Environment, Art. 26. 
to investigate and report, if there are "reasonable grounds for believing that a vessel ... has violated the international rules and standards regardless of where the violation occurred"; ${ }^{80}$ a right to enforce dumping standards; ${ }^{81}$ and a right to institute proceedings if a violation of international discharge standards has occurred in the territorial sea or within an as yet unspecified distance from the coast of either the port state or another state which is a party to the Convention containing the relevant standards and which requests such action by the port state. ${ }^{82}$ The port state may arrest the vessel, which is subject to release upon the posting of bond or other reasonable security; ${ }^{83}$ the port state must give the flag state six months to institute proceedings before instituting its own proceedings, and thereafter cannot proceed if the flag state "has previously commenced proceedings and has not discontinued those proceedings." ${ }^{44}$ Safeguards with respect to port state proceedings include the vessel-release requirement referred to, provisions on double jeopardy and "statute of limitations," and a provision permitting only monetary penalties. ${ }^{85}$

Thirdly, if a coastal state has reasonable grounds for believing a vessel has violated international discharge standards within an as yet unspecified distance from its coast, it may require identification and other specified information, including the next port of call, from the vessel "by radio or other means of communication." 88 Where the discharge violation has been of a "flagrant character causing severe damage or threat of severe damage to the marine environment, or the vessel is proceeding to or from the internal waters of the coastal State," the coastal state has the power to board and inspect..$^{87}$ It is required to notify the flag state ${ }^{88}$ and it can also request an investigation and proceedings by a port state..$^{80}$

Chapters Six and Seven "do not affect the legal regime of straits used for international navigations" as the relevant pollution provisions regarding transit passage are in the straits articles. ${ }^{00}$ The same result should presumably apply to "archipelagic sealanes passage" for the same reason. ${ }^{91}$

While there is general agreement on the need for safeguards, the actual enforcement powers of port states and coastal states are likely to continue to be controversial. For example, the United States and others have argued that there are sound environmental reasons not to limit port state enforcement of discharge violations to discharges in specific zones off the coast. Some will regard the coastal state enforcement rights at sea as too broad, and others as too restricted. The question of recourse to compulsory dispute settlement to ensure that environmental duties are met and

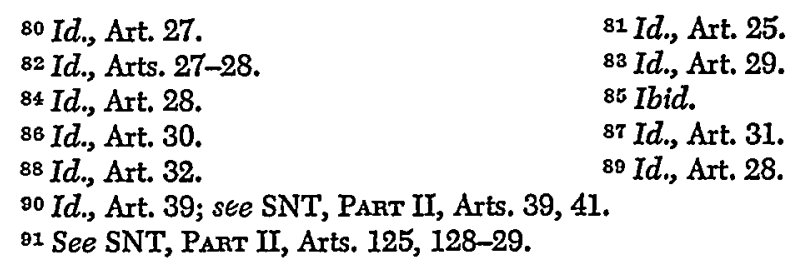


that exercise of environmental powers is in conformity with the Convention is critically related to the substance of the articles. ${ }^{92}$

The remaining chapters contain provisions on responsibility and liability, ${ }^{93}$ vessels entitled to sovereign immunity, ${ }^{94}$ other environmental conventions, ${ }^{25}$ and a general cross-reference to the chapter on compulsory dispute settlement.96

\section{Marine Scientific Research}

Negotiations on the question of research in the economic zone and on the continental shelf dominated the work of an informal negotiating group on marine scientific research. They proved very difficult.

The basic difference centered on whether, as proposed in a document reintroduced with only minor changes on behalf of the Group of $77,{ }^{97}$ such research should be subject to coastal state consent or, as proposed by other countries, including developed and developing landlocked and geographically disadvantaged countries, ${ }^{98}$ such research should be subject to certain obligations to the coastal state, including notification, participation, and data sharing, with preliminary dispute-settlement procedures to ensure fulfillment of the obligations prior to undertaking the research project. The view of the United States was that the conditions for scientific research should be agreed in the treaty and subject to compulsory dispute settlement in order to protect the interests of the coastal state and the international community and that this obviates the need for and dangers of consent. Moreover, the fact that drilling for all purposes on the continental shelf would be controlled exclusively by the coastal state ${ }^{99}$ meets the major arguments for a consent regime.

Early in the session, the U.S.S.R. and other Socialist countries introduced a formal proposal that would require coastal state consent for research "related to the exploration and exploitation of living and non-living resources," while other scientific research would be subject to a series of treaty obligations. ${ }^{100}$ The idea of distinguishing between types of research thereafter dominated the discussions. Needless to say, supporters and opponents of a consent regime noted the difficulties of making such distinctions but were aware of the potential for accommodation in such an

92 SNT, PART III, Protection and Preservation of the Marine Environment. Article 44 provides:

Any dispute with respect to the interpretation or application of the provisions of this Convention with respect to the preservation of the marine environment shall be resolved by the dispute settlement procedures contained in Chapter — of this Convention.

93 Id., Art. 41.

95 Id., Art. 43.

a. Id., Art. 42.

${ }^{96}$ Id., Art. 44, note 92 supra.

${ }^{97}$ A/CONF.62/C.3/L.13/Rev.1, April 4, 1975; Rev. 2, April 21, 1975; see the earlier Caracas text, A/CONF.62/C.3/L.13, discussed by the authors at 69 AJIL 28 (1975).

${ }^{98}$ A/CONF.62/C.3/L.28, April 24, 1975, amending the Caracas text, A/CONF.62/ C.3/L.19, discussed by the authors at 69 AJIL 28 (1975).

99 SNT, PART II, Art. 67.

${ }^{100}$ A/CONF.62/C.3/L.26, April 3, 1975. 
idea. In the closing days of the session, and after prior consultation with others, Colombia, El Salvador, Mexico, and Nigeria introduced a proposal ${ }^{101}$ which makes an analogous distinction between resource related research and fundamental scientific research.

The single negotiating text picks up this general approach. Scientific research in the economic zone or on the continental shelf would be subject to such requirements as notice to the coastal state, participation by the coastal state, provision of data and samples to the coastal state, assistance to the coastal state in assessing data, samples, and results, and international dissemination of results. ${ }^{102}$ Landlocked and geographically disadvantaged states in the region would also receive notice and have a right to participate "whenever feasible." 103

The notice to the coastal state must state whether the research project is "of a fundamental nature or related to the resources of the economic zone or continental shelf." 204 If the project is related to such resources, it is subject to coastal state consent and additional conditions, including a duty to "ensure that the research results are not published or made internationally available without the express consent of the coastal state." ${ }^{208}$ While this provision reflects the extreme sensitivities of some coastal states on the issue, the facile assimilation of scientific research regarding resources to commercial exploration is open to question. It is difficult to see what, if any, conceivable harm to a state which controls all exploitation could justify this obvious impediment to the acquisition and open dissemination of knowledge about the oceans. An essential element of progress in understanding natural features and processes is comparison; this requires the broadest possible data base.

Disagreements regarding the question whether research is fundamental are subject to relevant compulsory dispute-settlement procedures specified elsewhere in the Convention. ${ }^{106}$ There is also a general cross-reference to the dispute settlement Chapter. ${ }^{107}$

The remaining provisions on marine scientific research deal with the right to conduct scientific research beyond the economic zone and continental shelf,, ${ }^{108}$ scientific research installations and equipment, ${ }^{100}$ and responsibility and liability. ${ }^{110}$

\section{Development and Transfer of Technology}

The general provisions on development and transfer of technology establish a duty to cooperate in actively promoting "the development and trans-

${ }_{101}$ A/CONF.62/C.3/L.29, May 6, 1975.

102 SNT, PART III, Marine Scientific Research, Arts. 15-17, 22.

103 Id., Art. 23.

105 Id., Art. 21.

104 Id., Art. 18.

${ }^{106}$ Id., Art. 20.

107 Id., Art. 37.

108 Id., Arts. 25, 26; see SNT, PART I, Art. 10; PART II, Art. 75.

109 Id., Arts. 27-33; see SNT, PART II, Arts. 48, 66, 75.

110 Id., Arts. 34-36. 
fer of marine sciences and marine technology at fair and reasonable terms." 111 Specific reference is made to the development of the marine scientific and technological capacity of developing states. ${ }^{112}$ Specific duties are imposed on all states to "promote the acquisition, evolution and dissemination of marine scientific and technological knowledge," "promote training and education," especially of developing country nationals, and "facilitate access to scientific and technological information and data." 113 The chapter on international cooperation calls, among other things, for states to "promote the establishment of universally accepted guidelines" for the transfer of marine technology.114

With respect to the international seabed area, the international Authority would be required to ensure, inter alia, that developing country nationals "be taken on under training as members of the managerial, research and technical staff constituted for its undertakings," and would be called upon to conduct other training and dissemination of information. ${ }^{115}$ The Committee I text itself deals with transfer of technology and participation of developing countries in activities in the deep seabed area. ${ }^{118}$ The extent to which developing country positions in Committee I are in fact motivated by the desire to use the international seabed Authority as a vehicle for increased participation and training in the development and use of advanced and highly sophisticated marine technology is unclear. It could of course be quite relevant to the more industrialized of those countries, but would not seem very relevant to the development needs and priorities of the less developed or, indeed, the wealthier but as yet unindustrialized states in that group.

\section{Settlement of Disputes}

The single negotiating text on settlement of disputes "is based to a considerable extent on the work of the Informal Group on the Settlement of Disputes," and "seeks to blend ... the essence of the various alternatives" presented. ${ }^{117}$ While not official, the Group was open to all Conference participants, was attended at one time or another by representatives from more than 60 countries, and held announced regular meetings. The Co-Chairmen of the Group consulted informally with the President of the Conference and the Chairmen of the Main Committees on its work.

Some states, including the United States, have publicly stated that agreement on compulsory dispute settlement is an essential element of an overall "package." There is no reason to believe their position on this issue will change. There is simply too much room in the treaty for misunderstanding, abuse of power, and interference with rights on the basis of unilateral interpretation.

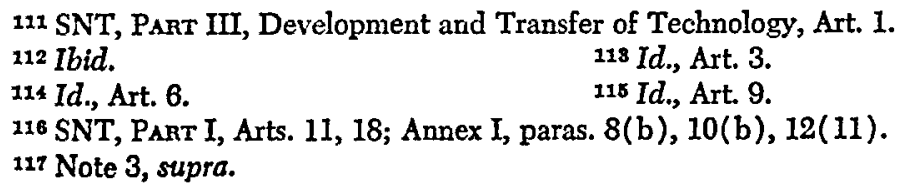


Since this issue of the Journal fortunately contains an analysis of the dispute settlement issues and texts by Mr. A. O. Adede, one of the CoChairmen of the Dispute Settlement Group, ${ }^{118}$ the authors will confine themselves to a comment on one of the main issues.

Attempts were made at Geneva to exclude the economic zone as a whole from compulsory dispute settlement. These attempts were strongly, widely, and properly resisted. This resistance came from states, like the United States, that supported provisions protecting the exercise of resource management discretion by the coastal state in accordance with the Convention. ${ }^{119}$ It is no accident that proponents of a 200-mile territorial sea or its equivalent were among the active proponents of excluding the economic zone from dispute settlement. The essential issue is an accommodation that guarantees not only coastal, but international, rights in the 200-mile economic zone. If it is the perception of the "territorialists" that an economic zone without compulsory dispute settlement will evolve into a territorial sea, that may also be the perception and the concern of those who have major interests in the protection of navigational and other freedoms.

This is not a peripheral or procedural issue; it is substantive. If states cannot resort to international adjudicatory procedures to protect their rights, they are ultimately faced with the same problems arising from unilateral treaty interpretation that arise from unilateral claims. If their own interests are not adequately protected, what then is the incentive for states to accept a treaty that will inevitably contain rules designed to accommodate interests they do not share?

Most states have far greater interests in protecting navigation than in protecting fishing in the economic zones of other states. Without minimizing the importance of compulsory dispute settlement to fishing issues, it would be foolhardy to expect the majority of coastal states to accept compulsory dispute settlement with respect to fishing that was not part of a broader compulsory dispute settlement system which includes navigation. In this sense, the debate over general and functional approaches to dispute settlement, discussed by Mr. Adede, has assumed dangerous dimensions. The question of the type of forum or forums to be used for settling disputes is not all that difficult to resolve; ${ }^{120}$ but the debate is obscuring the broader

118 See A. O. Adede, Settlement of Disputes Arising under the Law of the Sea Convention, infra p. 798.

${ }_{110}$ See SNT (Settlement of Disputes) Art. 18; Working Paper on Settlement of Disputes, Annex I, Art. 17, note 3 supra.

120 The question of forum is one basic difference between the general approach to dispute settlement in Annex I and the functional approach in Annex II of the Working Paper of the Dispute Settlement Group. In an attempt to accommodate differences on this matter, Article 6 of the single negotiating text gives preference to special (that is functional) procedures where the treaty provides for such procedures, and Article 9 provides that if both parties to the dispute have previously declared that they accept the jurisdiction of an arbitral tribunal, or the International Court of Justice, then "either party may submit the dispute to that tribunal" rather than to the new Law of the Sea Tribunal. 
issue of acceptance of binding third-party dispute settlement in the economic zone, a matter vital to the success of the Conference.

\section{Conclusion}

Aspirations for successful completion of the Conference have not been met in 1975. It remains unclear whether these aspirations will be met in 1976. This depends in part on whether there is sufficient political will to make the additional accommodations necessary for success, and whether adequate time is provided for both informal work and Conference sessions. One eight-week Conference session is almost certainly not enough.

The central procedural manifestation of progress toward a widely acceptable treaty is likely to be the approach taken to the single negotiating texts. If the Conference is beset by a plethora of amendments from individual states or groups on which it is compelled to take formal action, the chances for its early and successful completion will be reduced. There are simply too many points, some seemingly minor, where isolated decisions could preclude general agreement. On the other hand, if there is a frank and realistic assessment of the extent to which the texts do not reflect an adequate basis for widespread agreement and intensive negotiation designed to resolve the problems by widely agreed amendments, the chances for success are substantial. 